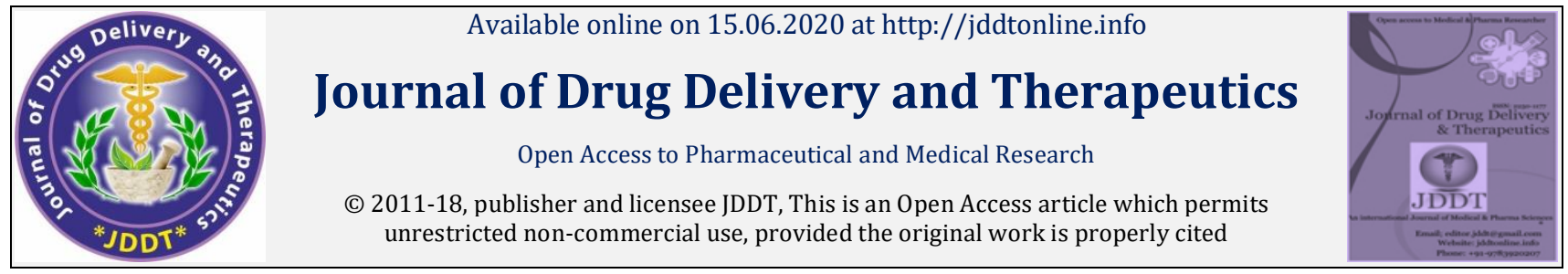

Open Access

Research Article

\title{
Studies on Antioxidant and Anti-obesity Activity of Salvia hispanica (Chia) Seeds Extracts
}

\author{
Subbaiyan Rubavathi *, Ganesan Ayyappadasan, Nagarajan Sangeetha, Thangavel Harini, Dhanuskodi \\ Saranya and Prakash Harshapradha
}

Department of Biotechnology, K.S. Rangasamy college of Technology, Tiruchengode - 637 215, Namakkal, Tamil Nadu, India

\begin{abstract}
Obesity is a condition in which large amount of fat is stored in adipose tissue. Obesity is the greatest risk for many diseases like coronary heart disease, type 2 diabetes millions associated with insulin resistance, arthritis disorder, hypertension and cancers. Currently, the available drugs for obesity have been associated with number of side effects when compared with allopathic drugs. Salvia hispanica was one of the member of Lamiaceae family, collected to study the antiobesity activity. Extraction of Salvia hispanica using different solvents was done and tested for the presence of phytochemical constituents and the antimicrobial activity was monitored to evaluate the zone of inhibition. Further, antioxidant potential activity such as DPPH, FRAP and $\mathrm{H}_{2} \mathrm{O}_{2}$ assay was studied. Percentage of inhibition of Salvia hispanica was calculated and was observed as in capturing the free radicals present in the body. The surface and cross-sectional morphology Salvia hispanica extract nanoparticles was examined by using SEM. High ALA content make chia a perfect as it is associated with lower incidence of Cardiovascular diseases. This metabolic syndrome is mediated by inflammatory pathways. Hence, the in vitro activity of anti-inflammatory assay was performed by inhibition of albumin denaturation and anti-obesity activity was performed by lipase inhibition assay. Thus the result indicates that the seed extracts of Salvia hispanica possess antiobesity activity.
\end{abstract}

Keywords: Salvia hispanica, anti-obesity, cholesterol, Antioxidant, lipase inhibition

Article Info: Received 26 March 2020; Review Completed 23 May 2020; $\quad$ Accepted 29 May 2020; Available online 15 June 2020

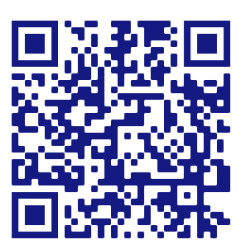

Cite this article as:

Rubavathi S, Ayyappadasan G, Sangeetha N, Harini T, Saranya D, Harshapradha P, Studies on Antioxidant and Anti-obesity Activity of Salvia hispanica (Chia) Seeds Extracts, Journal of Drug Delivery and Therapeutics. 2020; 10(3-s):98-106 http://dx.doi.org/10.22270/jddt.v10i3-s.4169

*Address for Correspondence:

Rubavathi Subbaiyan, Department of Biotechnology, K.S. Rangasamy college of Technology, Tiruchengode - 637 215, Namakkal, Tamil Nadu, India

\section{INTRODUCTION}

Salvia hispanica, is a biannually cultivated plant, is categorized under the family (Labiatae), super division of Spermatophyta, and kingdom of Plantae. Obesity is severe metabolic disorder in which excess body fat has accumulated in our body to the extent which may cause severe side effect on health leading to increased health problems ${ }^{1}$. Obesity is caused by an imbalance between energy intake and expenditure. Currently, no pharmacological treatment provides to reduce obesity with minimal side effects ${ }^{2}$. Chia seeds are high in phenolic compounds which have been scientifically proven to exhibit antioxidant related functions ${ }^{3}$. The plant seeds showed various pharmacological activities like cytotoxic, antiinflammatory, antioxidant, antiproliferate, antimicrobial, hypolipidemic and hypoglycemic activities ${ }^{4}$.

Chia seeds when placed in water produce a gel, this gel have good water binding capacity, oil holding capacity, viscosity

ISSN: 2250-1177 and emulsion activity. Chia seeds are a good source of fatty acids, dietary fiber, protein, minerals and antioxidants. Oil extracted from chia seeds can also be used in food ${ }^{3}$. Chia seed are high in phenolic compounds which have been scientifically proven to exhibit antioxidant related functions. Chia is one of the highest sources for omega-3, which is essential for maintaining healthy cholesterol level, brain development, immune system and it has anti-inflammatory effect. Chia seeds are better than using herbal plants and other pharmaco drugs for Obesity. A variety of natural products, including crude extracts and isolated pure natural compounds can induce body weight reduction and prevent diet-induced obesity. Therefore, they have been widely used in treating obesity 5 . It was observed that chia seeds decrease total cholesterol level and increases LDL cholesterol.

Chia seeds are a rich source of dietary fiber, which reduces the hunger sensation, and the omega-3 FA ALA, which is essential for the emulsification and absorption of the liposoluble vitamins $\mathrm{A}, \mathrm{D}, \mathrm{E}$, and $\mathrm{K}^{6}$. Chia oil improved CODEN (USA): JDDTAO 
glucose metabolism and promoted the browning process and a healthier phenotype ${ }^{7}$. Chia seeds may help in the prevention, treatment and management of several noncommunicable diseases, improving immunity and perhaps modifying the blood clotting mechanism. If chia seeds are added to food, they may improve their nutritional value and prevent many types of diseases. The potential of natural products for treating obesity is under exploration. This may be an excellent alternative strategy for developing future effective, safe anti-obesity drugs.

The present study deals with the antioxidant and antiobesity activity of the chia seeds which in turns helps out for the development of anti-obesity drugs with no side effects in future.

\section{MATERIAL AND METHODS}

\section{Collection of Salvia hispanica Seeds}

The chia (Salvia hispanica) seeds are procured from standard health food stores, Coimbatore. The chia seeds were cleaned by removing all the impurities and damaged seeds and stored for further experiments. The seeds were crushed and flour were stored in air tight container in normal room temperature.

\section{Preparation of Extract from Salvia hispanica Seeds}

Chia (Salvia hispanica) seed powder of about $10 \mathrm{~g}$ was weighed and taken in Soxhlet apparatus containing $100 \mathrm{ml}$ of hexane, ethyl acetate, methanol and water were run at $50^{\circ}$ C, for about 5-6 hours. Extract was concentrated using rotary evaporator at $50^{\circ} \mathrm{C}$ dried using lyophilizer to obtain powder. The immiscible oil is removed from the extract using percolation with hexane and oil-free extract were obtained8.

\section{Mineral Analysis of Salvia hispanica Seeds}

Mineral content like Phosphorous, Potassium, Magnesium, Manganese, Zinc, Calcium, Sulphur, Copper, Chromium, Arsenic, Nickel, Aluminium, Sodium, Ash was determined using Atomic adsorption spectrophotometer as per the method suggested by the Association of Official Analytical Chemists (AOAC) ${ }^{3}$.

\section{Proximate Analysis of Salvia hispanica Seeds}

The moisture content was determined by drying $2 \mathrm{~g}$ of chia seeds at $105^{\circ} \mathrm{C}$ for $24 \mathrm{hrs}$ and the total ash content was determined by incineration of samples. The crude fibre was determined by drying of sample. Total lipids of chia seeds were determined by using Soxhlet extractor ${ }^{\text {. }}$.

\section{Phytochemical Analysis of Salvia hispanica Seed Extract}

The standard protocols followed for the analysis of phytochemical constituents such as saponins, tannin, phenols, flavonoids, alkaloids and lipids 9 .

\section{DPPH Assay free radical scavenging activity}

1,1-diphenyl-2 picryl hydrazyl (DPPH) radical scavenging activity was used for evaluating the radical scavenging activity according to the established protocol 10 . Extracts solution of $20,40,60,80$ and $100 \mu \mathrm{g} / \mathrm{ml}$ were prepared using their respective solvents. Each test tube contained one $\mathrm{ml}$ of the sample and $2 \mathrm{ml}$ freshly prepared DPPH solution of $40 \mu \mathrm{g} / \mathrm{ml}$ in methanol. Negative control tubes were the same as the test tubes, except that they did not include DPPH. Absorbance of the mixture was recorded at $517 \mathrm{~nm}$ after 30 minutes. Ascorbic acid was used as a positive control. All samples were assayed in triplicate. The $\%$ inhibition activity was calculated as follows:
$\%$ inhibition $=$ [Absorbance of control- Absorbance of sample $]$ x 100/Absorbance of control

\section{FRAP Assay (Ferric Reducing Antioxidant Power)}

The ability of the seed extracts to reduce $\mathrm{Fe}^{3+}$ in ferric chloride to $\mathrm{Fe}^{2+}$ is visualized as a change in colour from yellow to green and was determined with minor modifications ${ }^{8}$. Approximately $1 \mathrm{ml}$ of either extract or standard $(20,40,60,80$ and $100 \mu \mathrm{g} / \mathrm{ml})$ was added to $2.5 \mathrm{ml}$ of PBS $(\mathrm{pH} 7.4,0.2 \mathrm{M})$ and $2.5 \mathrm{ml}$ of $1 \%$ potassium ferricyanide $\left[\mathrm{K}_{3} \mathrm{Fe}(\mathrm{CN})_{6}\right]$ and incubated for $20 \mathrm{~min}$ at $50^{\circ} \mathrm{C}$. Afterwards, $2.5 \mathrm{ml}$ of $10 \%$ trichloroacetic acid was added and the samples were centrifuged at $3000 \mathrm{rpm}$ for $10 \mathrm{~min}$. From this, $2.5 \mathrm{ml}$ of the supernatant plus $2.5 \mathrm{ml}$ distilled water and $0.5 \mathrm{ml}$ ferric chloride was mixed in a tube and the absorbance was measured at 700nm. Ascorbic acid was used as standard and the assay was performed in triplicate. The standard for Ferric reducing antioxidant Power is expressed as the number of equivalents of ascorbic acid.

\section{Hydrogen peroxide scavenging activity}

The ability of seed extracts to scavenge hydrogen peroxide can be estimated 10 . A solution of hydrogen peroxide $(40 \mathrm{mM})$ is prepared in phosphate buffer $(50 \mathrm{mM} \mathrm{pH} 7.4)$. The concentration of hydrogen peroxide is determined by absorption at $230 \mathrm{~nm}$ using a spectrophotometer. Extract $(20,40,60,80$ and $100 \mu \mathrm{g} / \mathrm{ml})$ in distilled water is added to hydrogen peroxide and absorbance at $230 \mathrm{~nm}$ is determined after 10 min against a blank solution containing phosphate buffer without hydrogen peroxide. The percentage of hydrogen peroxide scavenging is calculated as follows:

$$
\% \text { scavenging } \mathrm{H}_{2} \mathrm{O}_{2}=\left[\left(\mathrm{A}_{\mathrm{i}}-\mathrm{A}_{\mathrm{t}}\right) / \mathrm{A}_{\mathrm{t}}\right] \times 100
$$

Where $A_{i}$ is the absorbance of control and $A_{t}$ is the absorbance of test.

\section{Determination of phenolic content}

The concentration of phenolics in chia seed extracts was determined using spectrophotometric method. Different solvent extracts in the concentration of $1 \mathrm{mg} / 1 \mathrm{ml}$ was used in the analysis. The reaction mixture was prepared by mixing $0.1 \mathrm{ml}$ of different solvent extract. To that add $2.5 \mathrm{ml}$ of $10 \%$ Folin-Ciocalteu's reagent dissolved in water and also $2.5 \mathrm{ml}$ of $7.5 \% \mathrm{NaHCO}_{3}$. Blank was concurrently prepared without extract. The samples were then incubated in a temperature at $45^{\circ} \mathrm{C}$ for $45 \mathrm{~min}$. The absorbance was determined using spectrophotometer at the wavelength of $765 \mathrm{~nm}$. The samples were prepared in triplicate ${ }^{8}$.

\section{Determination of flavonoid content}

Total flavonoid content in the chia seed extract was measured by the aluminium chloride colorimetric assay. An amount of $1 \mathrm{ml}$ of different solvent extracts and standard solution of quercetin $(1 \mathrm{mg} / \mathrm{ml})$ was added to the test tube containing $4 \mathrm{ml}$ of distilled water. To this, $0.3 \mathrm{ml} 5 \% \mathrm{NaNO}_{2}$ was added and $0.3 \mathrm{ml} 10 \% \mathrm{AlCl}_{3}$ was added after incubation for $5 \mathrm{~min}$. After the incubation for $1 \mathrm{~min}, 2 \mathrm{ml}$ of $1 \mathrm{M} \mathrm{NaOH}$ was added to the test tube and the total volume was made up to $10 \mathrm{ml}$ with the distilled water. The solution was mixed well and the absorbance was measured against prepared reagent blank at $510 \mathrm{~nm}$. Total flavonoid content of seed extracts expressed as mg quercetin equivalents (QE)/100 g fresh weights. All samples were analysed in triplicates ${ }^{11}$.

\section{Synthesis and Characterization of Silver Nano Particles}

To $90 \mathrm{ml}$ of 3mM AgNO3 solution, $10 \mathrm{ml}$ of seed extract of the solvents (methanol and water) was added separately to two conical flasks, stirred at $200 \mathrm{rpm}$ using magnetic stirrer 
for 3hrs and kept under dark at room temperature for 24hours. Characterization of silver nanoparticles was done using UV-vis spectroscopy and SEM analysis. The surface and cross-sectional morphology of the Salvia hispanica seed extracts particles were examined by using Scanning Electron Microscopy ${ }^{12}$.

\section{Estimation of Total Cholesterol of Seed Extracts}

The total cholesterol level in different seed extracts was analysed by Zak's method to identify the amount of cholesterol present in seed extracts. In this, $5 \mathrm{ml}$ of $0.5 \%$ Ferric chloride in acetic acid reagent and $5 \mathrm{ml}$ of standard solution of $1 \mathrm{mg} / \mathrm{ml}$ cholesterol was taken into well cleaned dry test tube marked as B and S. $5 \mathrm{ml}$ of different seed extracts was added into the test tube marked as $\mathrm{T}_{1}, \mathrm{~T}_{2} \& \mathrm{~T}_{3} .3$ $\mathrm{ml}$ of concentrated $\mathrm{H}_{2} \mathrm{SO}_{4}$ was added to all the test tubes and allowed to stand for $20 \mathrm{~min}$ at room temperature. The intensity of reddish pink colour developed was measured calorimetrically at $560 \mathrm{~nm}$.

\section{Effect of Salvia hispanica seed extract on Lipase inhibition activity}

Lipase inhibition activity was measured using p-nitrophenyl butyrate (p-NPB) as a substrate. Stock solutions $(1 \mathrm{mg} / \mathrm{ml})$ were prepared by $0.1 \mathrm{mM}$ potassium phosphate buffer $(\mathrm{pH}$ 6.0 ) and the solutions were stored in $-20^{\circ} \mathrm{C}$. The extracts of different concentrations and orlistat (same concentration used for extracts) as a positive control were preincubated at potassium phosphate buffer for $1 \mathrm{~h}$ at $30^{\circ} \mathrm{C}$ before assaying the activity. The reaction was started by adding the $0.1 \mu \mathrm{L}$ NPB as substrate, in all the tubes. After incubation at $30^{\circ} \mathrm{C}$ for 5 minutes, the activity was measured at $405 \mathrm{~nm}$ using UVVisible spectrophotometer ${ }^{13}$. \%inhibition= [Absorbance of control-Absorbance of sample $] \mathrm{x}$ $100 /$ Absorbance of control

\section{Inhibition of albumin denaturation}

The reaction mixture was consisting of the test extract at different concentration and $1 \%$ aqueous solution of bovine albumin fraction. $\mathrm{pH}$ of the reaction mixture was adjusted using small amount of $1 \mathrm{~N} \mathrm{HCl}$. Diclofenac sodium (10 mg) was used as a standard drug. The samples were incubated at $37^{\circ} \mathrm{C}$ for 20 minutes and then heated at $57^{\circ} \mathrm{C}$ for 20 minutes. After cooling the samples, the turbidity was measured spectrophotometrically at $660 \mathrm{~nm}$. The experiment was performed in triplicate ${ }^{14}$.

Percentage inhibition of protein denaturation was calculated as follows:

$\%$ Inhibition $=($ Control OD-Test OD $)$ X100 / Control OD

Where Control oD is the absorbance without sample, TestoD is the absorbance of sample extract / standard.

\section{RESULT AND DISCUSSION}

\section{Extraction of Phytochemical Constituents from Salvia hispanica}

The crude extracts were obtained from soxhlet apparatus using polarity based solvents and it was powdered using lyophiliser. The seed extracts of Salvia hispanica were tested for the presence of bioactive ingredients (phytochemicals) and the results were showed in the Table 3.1. The preliminary phytochemical screening tests of Salvia hispanica seed extracts were useful in lead to the drug discovery and development in the future.

Table 3.1 Phytochemical analysis of Salvia hispanica extracts

\begin{tabular}{|c|c|c|c|}
\hline Phyto constituents & Hexane & Ethyl acetate & Methanol \\
\hline Saponins & + & + & + \\
\hline Phenols (Ferric chloride) & + & + & + \\
\hline Tannins (Gelatin's test) & + & + & + \\
\hline Flavonoids (Alkaline reagent test) & - & - & + \\
\hline Alkaloids (Hager's test) & - & + & + \\
\hline Lipids & + & + & + \\
\hline
\end{tabular}

\section{Mineral and Proximate Analysis of the Chia Seeds}

Mineral analysis shows the presence of macro elements and microelements such as Calcium, Iron, Magnesium, Phosphorus, Potassium, Sodium, Zinc in Salvia hispanica. Our results resemble like ${ }^{3}$. They play a vital role in various metabolic activities and responsible for normal growth and function of various organ systems and it is associated with prevention of cardiovascular diseases. The amount of proximate content present in Salvia hispanica seeds is given in the Table 3.2.
Table 3.2 Proximate chemical composition (\%) of Salvia hispanica seeds

\begin{tabular}{|c|c|}
\hline $\begin{array}{c}\text { Chemical } \\
\text { composition }\end{array}$ & $\begin{array}{c}\text { Mean } \pm \text { Standard } \\
\text { deviation }\end{array}$ \\
\hline Moisture & $7.82 \pm 0.06$ \\
\hline Ash & $4.77 \pm 0.09$ \\
\hline Crude protein & $18.65 \pm 0.06$ \\
\hline Total lipids & $35.80 \pm 0.15$ \\
\hline Crude fibre & $22.78 \pm 0.98$ \\
\hline
\end{tabular}


Table 3.3 Evaluation of mineral content in Salvia hispanica seeds

\begin{tabular}{|c|c|}
\hline Minerals/100g & Amount present (mg) \\
\hline Calcium & 631 \\
\hline Iron & 7.72 \\
\hline Magnesium & 335 \\
\hline Phosphorus & 860 \\
\hline Potassium & 407 \\
\hline Sodium & 16 \\
\hline Zinc & 4.58 \\
\hline Copper & 0.11 \\
\hline Chromium & 9.53 \\
\hline Arsenic & 0.16 \\
\hline Nickel & 0.19 \\
\hline
\end{tabular}

\section{Phenolic Estimation}

Phenolic compounds are commonly found in plants and its seeds are reported to have various biological activities Table
3.4 revealed that methanolic extract of $46.126 \pm 0.027 \mu \mathrm{g} / \mathrm{ml}$ shows higher phenolic content as compared to other solvent extracts followed by water extract of $44.717 \pm 0.025 \mu \mathrm{g} / \mathrm{ml}$. This report shows that phenolic compounds are more in methanol and water extracts than other solvent extracts. Phenols act as primary antioxidants or free radical scavengers. Further they are responsible for the activities like inhibition of lipid accumulation and differentiation or induction of apoptosis. 11 revealed the presence of high contents of phenolic in the methanol and water extract compared to other extracts. Hence it prevent the cells from cell damage during oxidative stress

\section{Flavonoid estimation}

Flavonoid compounds are commonly found in plants and its seeds it is reported to have various biological activities including antioxidant activity. Methanolic extract of chia seeds shows better activity of $88.975 \pm 0.033 \mu \mathrm{g} / \mathrm{ml}$ as compared to other seed extracts and followed by water extract of chia seed shows better activity of $76.876 \pm 0.020$ next to methanolic extract were represented in the Table 3.5. The compound quercetin is used as standard which contain flavonoids. It enables to scavenge the free radicals. ${ }^{11}$ revealed the presence of high contents of phenolic in the methanol and water extract compared to other extracts. Presence of these compounds in Salvia hispanica prevents the cells from cell damage during oxidative stress.

Table 3.4 Phenolic estimation of different extracts

\begin{tabular}{|c|c|c|c|c|c|}
\hline Concentration & 40 & 80 & 120 & 160 & 200 \\
\hline Std values & 1.015 & 1.495 & 2.298 & 2.968 & 3.097 \\
\hline \multicolumn{6}{|c|}{ HEXANE } \\
\hline 0D@765nm & 0.156 & 0.375 & 0.550 & 0.661 & 0.755 \\
\hline $\begin{array}{l}\text { Equilance of Gallic } \\
\operatorname{acid}(\mu \mathrm{g} / \mathrm{ml})\end{array}$ & $-4.69 \pm 0.03$ & $9.26 \pm 0.02$ & $20.26 \pm 0.03$ & $27.30 \pm 0.03$ & $33.21 \pm 0.02$ \\
\hline \multicolumn{6}{|c|}{ ETHYL ACETATE } \\
\hline OD@765nm & 0.169 & 0.351 & 0.517 & 0.627 & 0.735 \\
\hline $\begin{array}{l}\text { Equilance of Gallic } \\
\operatorname{acid}(\mu \mathrm{g} / \mathrm{ml})\end{array}$ & $-3.87 \pm 0.02$ & $7.66 \pm 0.02$ & $18.17 \pm 0.01$ & $25.11 \pm 0.03$ & $31.94 \pm 0.016$ \\
\hline \multicolumn{6}{|c|}{ METHANOL } \\
\hline 0D@765nm & 0.249 & 0.464 & 0.656 & 0.780 & 0.950 .7369 \\
\hline $\begin{array}{l}\text { Equilance of Gallic } \\
\operatorname{acid}(\mu \mathrm{g} / \mathrm{ml})\end{array}$ & $1.21 \pm 0.02$ & $14.83 \pm 0.02$ & $26.99 \pm 0.0312$ & $32.05 \pm 0.02$ & $46.126 \pm 0.02$ \\
\hline \multicolumn{6}{|c|}{ WATER } \\
\hline OD@765nm & 0.251 & 0.352 & 0.551 & 0.662 & 0.810 \\
\hline $\begin{array}{l}\text { Equilance of Gallic } \\
\text { acid }(\mu \mathrm{g} / \mathrm{ml})\end{array}$ & $1.18 \pm 0.03$ & $7.75 \pm 0.02$ & $20.34 \pm 0.03$ & $27.32 \pm 0.04$ & $44.71 \pm 0.02$ \\
\hline
\end{tabular}


Table 3.5 Flavonoid estimation of different extracts

\begin{tabular}{|c|c|c|c|c|c|}
\hline Concentration & 40 & 80 & 120 & 160 & 200 \\
\hline Std values & 0.652 & 0.865 & 1.234 & 1.312 & 1.518 \\
\hline \multicolumn{6}{|c|}{ HEXANE } \\
\hline OD@420nm & 0.342 & 0.453 & 0.736 & 0.837 & 0.890 \\
\hline $\begin{array}{c}\text { Equilance of } \\
\text { quercitin }(\mu \mathrm{g} / \mathrm{ml})\end{array}$ & $-24.9 \pm 0.4$ & $-4.28 \pm 0.03$ & $48.12 \pm 0.03$ & $66.70 \pm 0.03$ & $70.6 \pm 0.01$ \\
\hline \multicolumn{6}{|c|}{ ETHYL ACETATE } \\
\hline OD@420nm & 0.347 & 0.527 & 0.643 & 0.780 & 0.851 \\
\hline $\begin{array}{c}\text { Equilance of } \\
\text { quercitin }(\mu \mathrm{g} / \mathrm{ml})\end{array}$ & $-24 \pm 0.04$ & $9.29 \pm 0.01$ & $30.83 \pm 0.02$ & $56.20 \pm 0.01$ & $69.29 \pm 0.035$ \\
\hline \multicolumn{6}{|c|}{ METHANOL } \\
\hline OD@420nm & 0.455 & 0.546 & 0.657 & 0.893 & 0.962 \\
\hline $\begin{array}{c}\text { Equilance of } \\
\text { quercitin }(\mu \mathrm{g} / \mathrm{ml})\end{array}$ & $-3.91 \pm 0.1$ & $12.87 \pm 0.028$ & $33.49 \pm 0.03$ & $66.086 \pm 0.04$ & $88.97 \pm 0.03$ \\
\hline \multicolumn{6}{|c|}{ WATER } \\
\hline oD@420nm & 0.161 & 0.345 & 0.646 & 0.751 & 0.870 \\
\hline $\begin{array}{c}\text { Equilance of } \\
\text { quercitin }(\mu \mathrm{g} / \mathrm{ml})\end{array}$ & $-58 \pm 0.03$ & $-24.3 \pm 0.044$ & $31.395 \pm 0.04$ & $50.59 \pm 0.03$ & $76.87 \pm 0.02$ \\
\hline
\end{tabular}

\section{Antimicrobial Activity}

\section{Antibacterial activity}

Extracts of seed were tested against bacteria. Hexane and ethyl acetate extract shows higher antimicrobial activity against the pathogen bacteria. In the methanol extract of chia seeds highest zone of inhibition was found at $25 \mathrm{~mm}$ and followed by ethyl acetate extract was found at $22 \mathrm{~mm}$ for $S$.aureus, revealed that both the aqueous and methanolic extract of Salvia hispanica exhibited high antibacterial effect against the pathogenic bacteria ${ }^{15}$.

Table 3.6 Antibacterial activity of seed extracts

\begin{tabular}{|c|c|c|c|c|}
\hline \multicolumn{5}{|c|}{ Zone of inhibition(mm) } \\
\hline Microorganisms & E.coli & K.pneumonia & B.subtilis & S.aureus \\
\hline Hexane Extract & $19 \pm 0.04$ & $14 \pm 0.05$ & $16 \pm 0.04$ & $18 \pm 0.09$ \\
\hline Ethyl acetate Extract & $10 \pm 0.04$ & $17 \pm 0.02$ & $12 \pm 0.12$ & $22 \pm 0.08$ \\
\hline Methanol Extract & $16 \pm 0.06$ & $15 \pm 0.08$ & $20 \pm 0.06$ & $\mathbf{2 5 \pm 0 . 0 3}$ \\
\hline Water Extract & $18 \pm 0.07$ & $16 \pm 0.09$ & $11 \pm 0.07$ & $15 \pm 0.09$ \\
\hline
\end{tabular}

\section{Antifungal activity}

The antifungal activity was performed against the fungus by using the different solvent extracts of Salvia hispanica. Methanol extract shows better antifungal activity than other seed extracts against $C$. albicans. The antifungal activity of methanolic extract of Salvia hispanica shows inhibition against bacterial pathogens such as Trichoderma $(9 \pm 0.04 \mathrm{~mm})$, A.oryzae $(7 \pm 0.06 \mathrm{~mm})$, C.albicans $(4 \pm 0.09 \mathrm{~mm})$, C. tropicans $(11 \pm 0.03)$. The results predicted that in methanol extract and followed by hexane extract shows better zone of inhibition for the pathogen $C$. Tropicans.

Table 3.7 Antifungal activity of seed extracts

\begin{tabular}{|c|c|c|c|c|}
\hline \multicolumn{5}{|c|}{ Zone of inhibition(mm) } \\
\hline Microorganisms & Trichoderma & A.oryzae & C.albicans & C.tropicans \\
\hline Hexane Extract & $4 \pm 0.01$ & $7 \pm 0.03$ & $5 \pm 0.04$ & $10 \pm 0.07$ \\
\hline Ethyl acetate Extract & $5 \pm 0.03$ & $8 \pm 0.02$ & $2 \pm 0.07$ & $9 \pm 0.08$ \\
\hline Methanol Extract & $9 \pm 0.04$ & $7 \pm 0.06$ & $4 \pm 0.09$ & $\mathbf{1 1 \pm 0 . 0 3}$ \\
\hline Water Extract & $6 \pm 0.07$ & $6 \pm 0.03$ & $9 \pm 0.08$ & $4 \pm 0.09$ \\
\hline
\end{tabular}




\section{Analysis of Antioxidant Activity}

\section{DPPH Assay}

The DPPH assay was performed to evaluate the reducing power of free radicals. The free radical scavenging activity was tested by its ability to bleach the stable DPPH radical. For the estimation of radical scavenging activity of Salvia hispanica, ascorbic acid is used as standard at different concentration ranges $(20,40,60,80,100 \mu \mathrm{g} / \mathrm{ml})$. The percentage inhibition of different extracts for Salvia hispanica at various concentration 20,40,60, 80, $100 \mu \mathrm{g} / \mathrm{ml}$ were calculated. From the resultant graph, it was found that methanol extract showed maximum free radical scavenging activity while hexane extract is least potent. ${ }^{11}$ deliberated that highest free radical scavenging observed in methanol fraction $(12.75 \mu \mathrm{g} / \mathrm{ml})$ since it contains highest amount of polyphenols \& flavonoids when compared to other extracts.

\section{\%inhibiton analysis of DPPH assay}

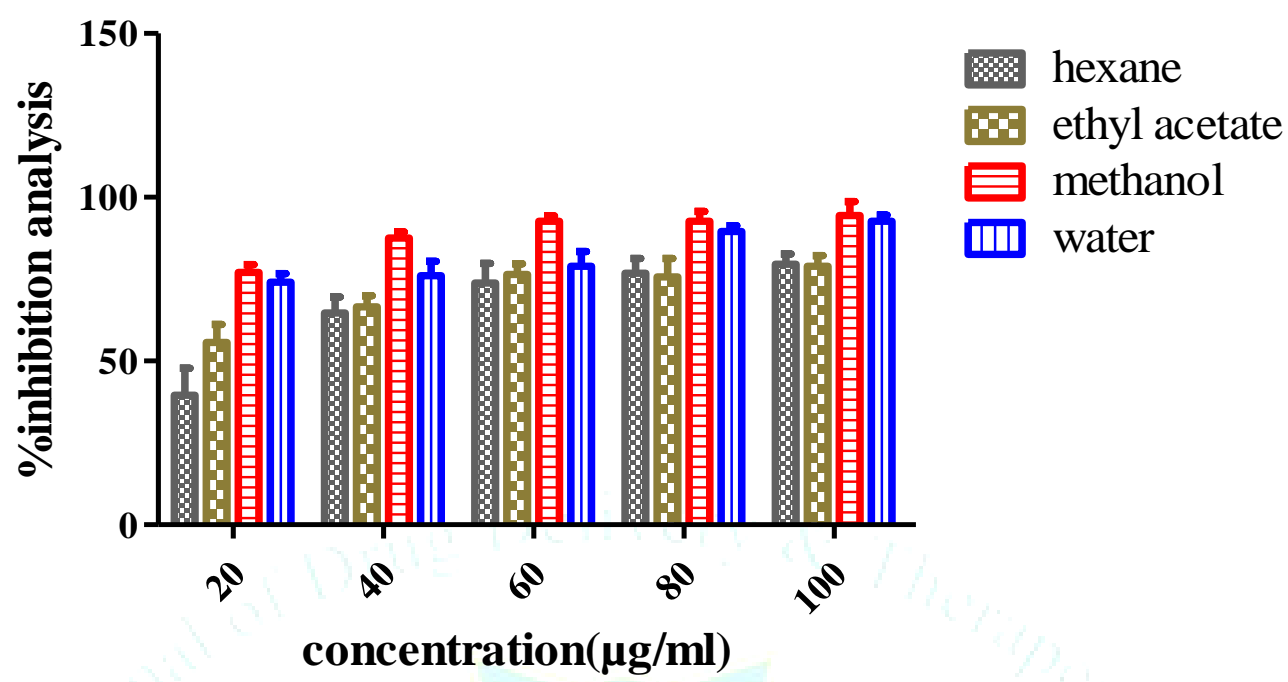

Figure 1: Evaluation of (\%) inhibition analysis of DPPH assay for different extracts of Salvia hispanica

\section{FRAP Assay}

In this present study, the ferric reducing ability of plasma as a measure of antioxidant power was analysed through reducing the free radicals. The Ferric reducing ability of plasma was performed with different seed extracts and compared with standard Gallic acid. The triplicate values are noted and the mean values were calculated. From the Figure2 it was shown that methanol extract of Salvia hispanica shows more reducing potential as antioxidants than the other extract. ${ }^{11}$ revealed that maximum inhibition activity observed in methanol extract.

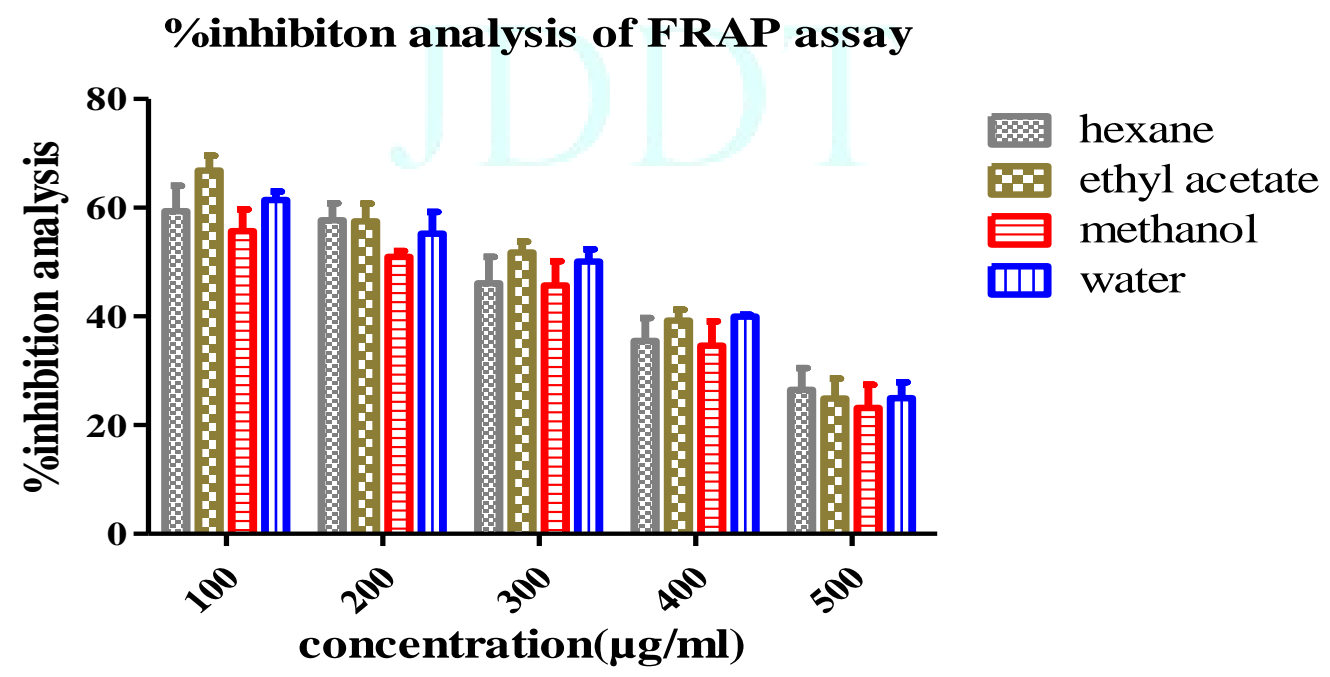

Figure 2: Evaluation of percentage (\%) inhibition analysis of FRAP assay for different extracts of Salvia hispanica

\section{Hydrogen peroxide radical scavenging activity}

Hydrogen peroxide has the ability to cross the cell membrane. Ascorbic acid is used as standard at different concentration ranges $(20,40,60,80,100 \mu \mathrm{g} / \mathrm{ml})$. The $\%$ inhibition of different extracts for Salvia hispanica at various concentrations $(20 \mu \mathrm{g} / \mathrm{ml}$ to $100 \mu \mathrm{g} / \mathrm{ml})$ was shown in the ISSN: 2250-1177
Figure 3. It implies that methanol extract of Salvia hispanica shows similar antioxidant to water extract. Our results are in line with ${ }^{8}$ when the concentration increases, the percentage inhibition for different extracts of Salvia hispanica also increases. It shows a maximum inhibition at the concentration of $100 \mu \mathrm{g} / \mathrm{ml}$. 


\section{\%inhibiton analysis of Hydrogen peroxide assay}

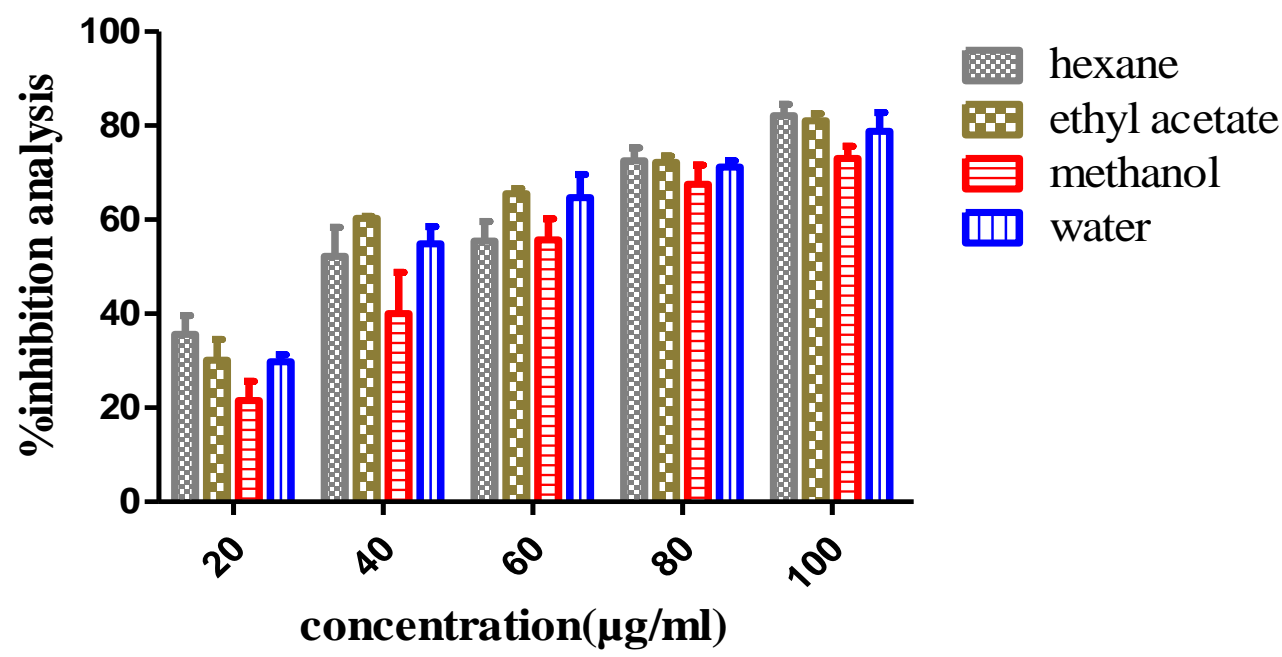

Figure 3: Evaluation of percentage (\%) inhibition analysis of Hydrogen peroxide assay for different extracts of Salvia hisp-anica

Characterization of Silver Nano Particles

\section{UV-Visible Spectroscopy analysis}

The absorption spectrum of the produced silver nanoparticles for the methanol and water extracts were found to be respectively. Generally AgNPs have high absorbance value in the visible range of $415-470 \mathrm{~nm}$. It was similar to that of 12.16 revealed that the ethyl alcohol extract has highest peak value of $445 \mathrm{~nm}$ respectively. The peaks with respect to water and methanol are noted as 1.903,1.849 respectively.
Scanning electron microscopy (SEM) analysis

The SEM image in figure 4 showed the density of silver nano particles (Ag-NPs) synthesized by Salvia hispanica. The typical SEM image shows the product mainly consist of spherical like particle size in the range $50 \mathrm{~nm}$. The surface deposited silver nanoparticles are seen at magnification 588X. The morphological structure was studied and the images are taken at the acceleration voltage of $4.00 \mathrm{kV}$. It has revealed that spherical shaped size AgNPs was reported to have 44-56 $\mathrm{nm}$ under magnification of X65,000.

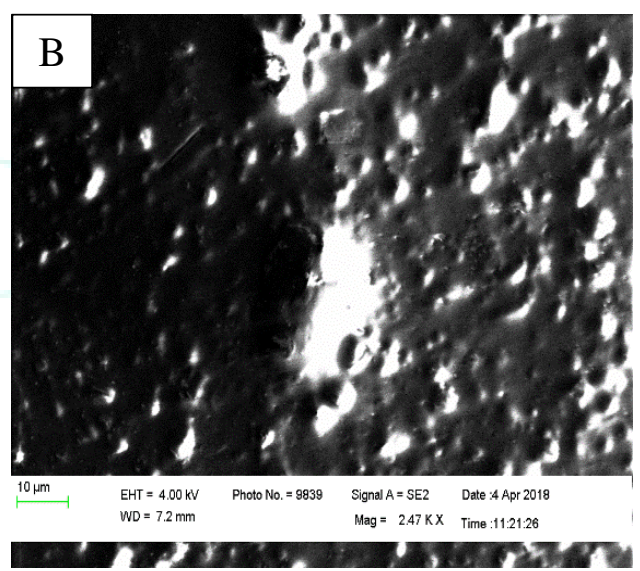

Figure 4: SEM micrographs of Salvia hispanica at various magnification

A. AgNPs+ Water Extract B. AgNPs+ Methanol Extract

\section{Assessment of In Vitro Anti-Inflammatory Activity Inhibition of albumin denaturation:}

Salvia hispanica is well known anti-inflammatory property and followed by 9 . This study, have shown inhibition of thermally induced protein (Albumin) denaturation in dose dependent manner, where the inhibition value is $94 \mu \mathrm{g} / \mathrm{ml}$ for AgNPs+ methanolic extract used diclofenac sodium as a standard. Compared to all other extracts AgNPs+methanol shows high inhibition value of anti-inflammatory activity compared to all other extracts. 


\section{Anti inflamatory Activity}

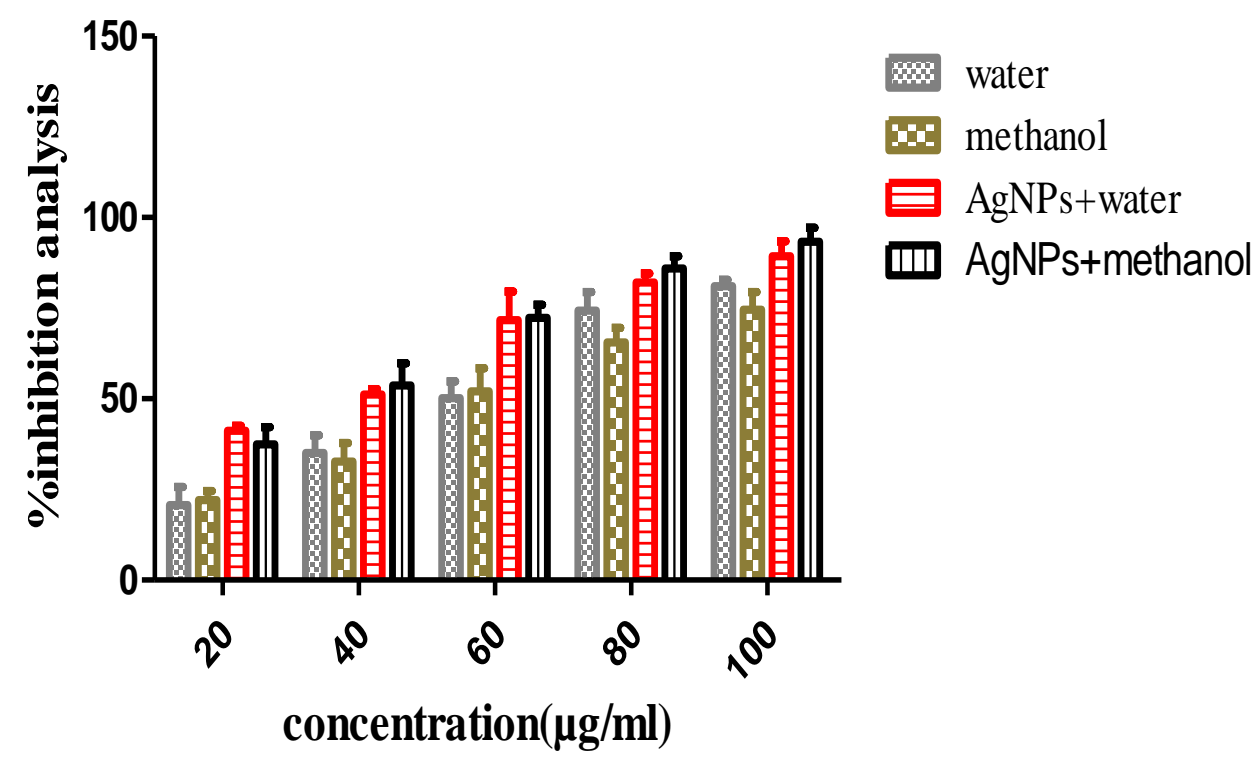

Figure 5: Determination of percentage radical scavenging activity for different extracts of Salvia hispanica using Protein denaturation assay

\section{Estimation of cholesterol in extracts of Salvia hispanica seeds}

The present study revealed the estimation of cholesterol level in hexane extract, ethyl acetate extract, methanol extract and water extract of Salvia hispanica. It revealed that the amount of cholesterol present in the Salvia hispanica extracts are very least potent. The amount of cholesterol level present in the methanol is very less amount when compared to other extracts. In $100 \mu$ l concentration the equivalence amount of cholesterol present in methanolic extract of Salvia hispanica is $5.801 \pm 0.001$ whereas in other extracts hexane is $5.94 \pm 0.006$, ethyl acetate is $6.101 \pm 0.009$ and water is $6.48 \pm 0.002$. Our results are in line with ${ }^{11}$ who evaluated the cholesterol level of Salvia hispanica by Zak's method.

\section{Effect of Salvia hispanica seed extract on lipase inhibition activity}

The anti-lipase activity was investigated at the different concentrations $(20,40,60,80,100 \mu \mathrm{g} / \mathrm{ml})$ for lipase inhibition. The different extracts such as hexane, ethyl acetate, methanol, water examined; methanolic extracts from seed at a concentration of $100 \mu \mathrm{g} / \mathrm{ml}$, significantly inhibited Lipase in vitro activity. Among the four of the extracts AgNPS+methanolic extracts showed a relatively high anti lipase activity of more than $70 \%$ respectively followed by AgNPs+water extract. Treatment with Orlistat as a positive control, a well-known anti-lipase agent significantly inhibited activity up to $82 \%$ used to compare the inhibitory activity of the extracts. 13 revealed that methanolic and aqueous extracts has high lipase inhibition activity in 20 $\mu \mathrm{g} / \mathrm{ml}$

Table 3.8 Estimation of cholesterol in different extracts of Salvia hispanica

\begin{tabular}{|c|c|c|c|c|c|}
\hline Concentration & 20 & 40 & 60 & 80 & 100 \\
\hline Std values & 0.396 & 0.65 & 1.172 & 1.889 & 1.947 \\
\hline \multicolumn{6}{|c|}{ HEXANE } \\
\hline OD@560nm & 0.0118 & 0.0261 & 0.0316 & 0.046 & 0.0516 \\
\hline $\begin{array}{c}\text { Equillance of } \\
\text { cholesterol }(\mu \mathrm{g} / \mathrm{ml})\end{array}$ & $4.02 \pm 0.04$ & $4.7 \pm 0.2$ & $5.02 \pm 0.07$ & $5.676 \pm 0.009$ & $5.94 \pm 0.006$ \\
\hline \multicolumn{6}{|c|}{ ETHYL ACETATE } \\
\hline OD@560nm & 0.0128 & 0.0315 & 0.0457 & 0.0527 & 0.0548 \\
\hline $\begin{array}{c}\text { Equillance of } \\
\text { cholesterol }(\mu \mathrm{g} / \mathrm{ml})\end{array}$ & $4.07 \pm 0.05$ & $4.975 \pm 0.004$ & $5.66 \pm 0.02$ & $6.001 \pm 0.001$ & $6.101 \pm 0.009$ \\
\hline \multicolumn{6}{|c|}{ METHANOL } \\
\hline OD@420nm & 0.012 & 0.0218 & 0.0308 & 0.0387 & 0.0486 \\
\hline $\begin{array}{c}\text { Equvillance of } \\
\text { cholesterol }(\mu \mathrm{g} / \mathrm{ml})\end{array}$ & $4.03 \pm 0.04$ & $4.50 \pm 0.04$ & $4.94 \pm 0.04$ & $5.234 \pm 0.001$ & $5.80 \pm 0.01$ \\
\hline \multicolumn{6}{|c|}{ WATER } \\
\hline 0D@420nm & 0.017 & 0.036 & 0.0467 & 0.0506 & 0.0628 \\
\hline $\begin{array}{c}\text { Equillance of } \\
\text { cholesterol }(\mu \mathrm{g} / \mathrm{ml})\end{array}$ & $4.275 \pm 02.2$ & $5.19 \pm 0.02$ & $5.17 \pm 0.01$ & $5.898 \pm 0.005$ & $6.48 \pm 0.02$ \\
\hline
\end{tabular}




\section{Anti Obesity activity}

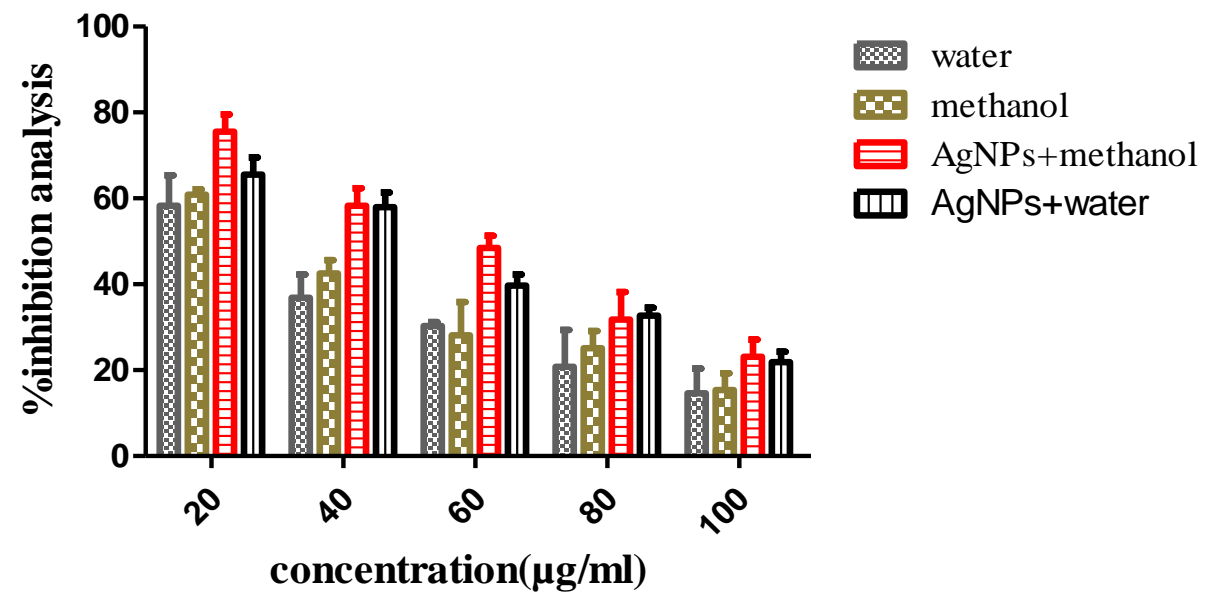

Figure 6: Determination of Anti-obesity activity for different extracts of Salvia hispanica using lipase inhibiton assay

\section{CONCLUSION}

The Salvia hispanica seed samples were extracted using polarity based solvents such as Hexane, Ethyl acetate, Methanol, Water using soxhlet apparatus. The results of present studies indicate that Methanolic extract shows highest antibacterial activity in S.aureus and highest antifungal activity in C.tropicans. Compare to all solvents, methanolic extract shows highest antioxidant activity in DPPH, FRAP, $\mathrm{H}_{2} \mathrm{O}_{2}$. Hence, supplement of Salvia hispanica seeds rich in compounds such as polyphenol and flavonoids can protect the cell from damage due to free radicals. The current studies provide a basis for further experiments on the identifications and characterization of specific compounds by silver Nano particle synthesis with relatively high antimicrobial and antioxidant activity. The particles were examined by using Scanning Electron Microscopy (SEM) to evaluate surface morphology. The synthesised particle was able to inhibit the inflammation. The AgNps+methanol shows highest inhibitory by albumin denaturation. In anti-obesity estimation the highest inhibition activity by lipase inhibition assay was possessed by AgNps+methanol at $20 \mu \mathrm{g} / \mathrm{ml}$ when compared to all other extracts. Among all the extracts, the methanol extract had highest fat inhibition activity. Thus the result indicates that the Salvia hispanica extracts possess antiobesity activity.

Acknowledgements: The authors are grateful to KSR College of Technology, India for providing tremendous facilities and support to carry out the work

\section{Conflicts of Interest: None}

\section{REFERENCES}

1. Ahmed KSZ, Sidhra, SZA, Ponmurugan, $P$ and Kumar BS, Ameliorative potential of Solanum trilobatum leaf extract and fractions on lipid profile and oxidative stress in experimental diabetes, Pak. J. Pharm. Sci, 2016 ; 29(5): 1571-1578.

2. Pagotto $U$, D. Vanuzzo, V. Vicennati, and R. Pasquali, "Pharmacological therapy of obesity," Giornale Italiano di Cardiologia, 2008; 9(4); 83-93.

3. Sukhneet S, Santosh JP and Goyat. J, "Chia seed: Salvia hispanica- A new age functional food", International Journal of Advanced Technology in Engineering and science, 2016; 4(3):978-86.

4. Sehrawat A, and Singh $S$, "Pharmacognostical standardization and preliminary phytochemical explorations on Salvia hispanica $L$. seeds", 2019; 9(1):139-143.
5. Bhutani JE, Potter JD, Jacobs DR, Kopher RA and Rourke MI, "Maternal waist-to-hip ratio as a predictor of newborn size: results of the diana project", Epidemiology, 2007; 7:62-66.

6. Silva CSD, Monteiro CRDA, Silva GHF., Sarni, ROS, Souza, FIS, Feder $D$ and Eberlin, M. N. "Assessing the Metabolic Impact of Ground Chia Seed in Overweight and Obese Prepubescent Children: Results of a Double-Blind Randomized Clinical Trial". Journal of Medicinal Food. 2020; 23:224-232.

7. Souza T, Silva, SV, Faria, T, Silva, V, Fidalgo, C, \& Citelli M “Chia oil induces browning of white adipose tissue in high-fat diet-induced obese mice". Molecular and Cellular Endocrinology, 2020; 48:538545.

8. Ayyappadasan G, Deepak kumar P, Rubavathi $S$ and Uthira $M$, “ Metabolite profiling and an invitro assessment of antimicrobial and antioxidant activities of lichen Ramalina inflata", International Research Journal of Pharmacy, 2017; 7(12):132138.

9. Gazem RA, Puneeth HR, Chakere SC and Chandrashekaraih S, "Physiochemical properties and invitro Anti-inflammatory effects of Indian chia (Salvia hispanica) seed oil", 2016; 11:01-08.

10. Rubavathi $S$ and Ramya M Invitro Assessment of Antimicrobial and Antioxidant Activity of Bioactive Compounds from Marine Algae. International Journal of Current Microbiology and Applied Sciences, 2016; 5 (7):253-266.

11. Patil MM, Anand T, Ilaiyaraja and Farhath K. "Invitro Antioxidant and Antiobesity properties of Bauhinia variegate", 2017;2:128132.

12. Premkumar $S$, Rubavathi $S$, and Robinson JP, Green Synthesis of Silver Nanoparticles using Barringtonia Acutangula (l.) Gaertn. and its Invitro Anticancer Property, International Journal of Advance Research, Ideas and Innovations in Technology, 2018; 3 (6):322-331.

13. Changhyun $R$ and Uhee J "Screening of crude plant extracts with Anti-obesity activity", Int J Mol Sci. 2012; 13:1710-1719.

14. Das B, Choudhury MD, Dey A, Talukdar AD, Nongalleima KH and Deb $L$ "Antioxidant and Anti-Inflammatory Activity of Aqueous and Methanolic Extracts of Rhizome Part of Drynaria Quercifolia (L.)" Internatonal journal of pharmacy and pharmaceutical sciences, 2014; 6:43-49.

15. Divyapriya GK, Veeresh DJ and Puja $C Y$ "Evaluation of Antibacterial efficacy of Chia seed extract against Porphyromonas Gingivalis, Fusobacterium. Nucleatum and Aggretibacter Actinomycetemcomitans- An in-vitro study", International journal of Ayurvedha, 2016; 4:2322- 2355.

16. Jyoti $S$, Vetriselvan $S$, Gayathiri $S$, Ishwin $S$, Shereenjeet $G$, Devi $C H$, and Yaashini A. "Comparitive evaluation of anti-inflammatory activity of extract of Curcuma longa and standard drug in carrageenan induced paw edema model using albino wistar rats" International journal of biological and pharmaceutical research, 2012; 3:538-544. 